\title{
Use of Effectuation by established micro businesses: Short-term gain, long-term pain?
}

Phillip McGowan

Marketing and Sales Subject Group

Faculty of Business and Law

Portsmouth Business School

University of Portsmouth

Richmond Building

Portland Street

Portsmouth

United Kingdom

PO1 3DE

E-Mail: phillip.mcgowan@port.ac.uk 


\section{Use of Effectuation by established micro businesses: Short-term gain, long-term pain?}

\section{Abstract}

Purpose: The purpose of this study is to investigate the efficacy and impact of effectual logic used by owner-managers of established micro firms when making buying decisions.

Design/methodology/approach: Semi-structured interviews were conducted with 13 owner-managers of micro firms, concerning their decision making processes when selecting suppliers. Interviews were transcribed verbatim, then analysed thematically.

Findings: This study contributes to the literature in respect of effectuation by considering its use by a micro firm owner-manager to develop relationships with trusted suppliers. Findings suggest effectuation positively promotes flexibility and reduces loss potential, thus, positively affecting the price that the owner-manager is willing to pay. Furthermore, it also appears to necessitate effectual selling, with an ongoing iterative process, in which effectual selling leads to effectual buying. In contrast to extant literature, this study suggests that application of effectual logic to buying and selling decisions, by a micro firm owner-manager can create, rather than reduce, uncertainty.

Research limitations/implications: This study is based on single interviews with a sample of owner-managers of micro firms that operate within the same industry and within a single country. The subjective nature of qualitative research, homogeneity and size of sample may prevent generalisation of the findings.

Practical implications: Effectual buying and selling appears to provide a micro firm with the ability to engage with flexible suppliers so as to offer a heterogeneous array of products and services to its customers, thus promoting sales success. Yet, the lack of homogeneity of customer needs and need for supplier flexibility may lead to overall costs being greater than those that could be achieved if the micro firm specialised in a smaller range of products and services and developed internal resources to meet the needs of its customers.

Originality/value: In contrast to extant literature that states that effectuation is a way to reduce uncertainty to a level at which a decision can be made, this study suggests that continual use of effectual logic by owner-managers of micro firms when making buying and selling decisions can instead create more uncertainty in the longer term.

Keywords: Effectuation, Micro firms, Buyer-supplier relationship, Networking, Effectual selling 


\section{Introduction}

Extant buying literature identifies differences between the procurement practices of large and micro firms (Ellegaard, 2006, 2009), yet little is known about the decision-making logic of micro firm owner-managers with respect to buying. Accordingly, this paper seeks to extend the work of McGowan (2018), published in volume 12 of the IMP Journal, and responds to his call for empirical investigation into the impact of the use of effectual logic by micro firm owner-managers in determining buying decisions.

Whilst it would appear that large firms employ trained professionals to conduct buying activities, in micro firms with limited resources, the owner-manager is more likely to take personal responsibility for buying activities (Ellegaard, 2006). The owner-manager, however, may not be formally trained in buying, may be less experienced and, consequently, as suggested by Ellegaard (2006), may rely on more informal practices. Decisions are, therefore, more likely to be based upon opinions than facts and, due to resource restrictions, an inability to access all options from the whole market (Seung-Kuk, Bagchi, Skjøtt-Larsen, \& Adams, 2009). This suggests that the processes used by large and micro firms may be different, with micro firms more likely affected by effectuation.

Effectuation theory, which is a combination of decision making heuristics, is posited as a logic used by entrepreneurs to support decision making in situations of uncertainty (Sarasvathy, 2009; Christopher Welter \& Kim, 2018) in which an owner-manager of a micro firm may rely on their personal means, skills and knowledge to arrive at a decision (Fisher, 2012).

'Effectuation is the inverse of causation. Effectual reasoning is not merely a deviation from causal reasoning; it is a distinct mode of reasoning based on an entirely separate logic than the logic behind causal reasoning' (Sarasvathy, 2001a, p. 1; 2001b). When applied to small firm buying decisions, it is claimed to explain the processes used by an owner-manager and suggests that they have a predilection for flexible commercial terms and trading with suppliers known to them through business and personal networks (McGowan, 2018).

The Industrial Marketing and Purchasing (IMP) group tradition suggests that the success of a firm may be significantly dependent upon a dyadic relationship with its customers and suppliers (Bordonaba-Juste \& Cambra-Fierro, 2009; Snehota \& Hakansson, 1995; Turnbull, Ford, \& Cunningham, 1996). Said inter-firm interactions require sufficient and appropriate allocation of resources by both sides of the dyad to promote long-term success (Davies \& Ryals, 2014; Ivens \& Pardo, 2016). Additionally, 'business interaction is often resource and investment intensive and commonly involves prioritizing between counterparts and processes' (Håkansson \& Ford, 2016, p. 169). 
Micro firms, however, lack resources to invest in relationships and processes, may lack depth of expertise and experience, and may thus be less able to plan for and cope with external influences (Huin, Luong, \& Abhary, 2002; Kavak, Tunçel, \& Özyörük, 2015a; Lenny Koh, Demirbag, Bayraktar, Tatoglu, \& Zaim, 2007; Morrissey \& Pittaway, 2006; Seung-Kuk et al., 2009; Thakkar, Kanda, \& Deshmukh, 2008). This leads to the suggestion that further investigation into how micro firms successfully undertake buying activities (McGowan, 2018) and engage in buying and selling relationships and networks while experiencing resource restriction (Bocconcelli et al., 2016), would be of interest to both scholars and practitioners.

This paper proceeds as follows: First, it presents a review of the literature starting with a review of effectuation (Sarasvathy, 2009), then it considers constructs relating to micro firm buying behaviour with propositions proposed in relation to the buying activities of owner-managers; specifically, how personal relationships and supplier flexibility positively impact the choice of products and services that form the sales strategy and customer proposition of the micro firm. A short description of methods used to conduct empirical research is followed by presentation of findings and a discussion. The final section outlines conclusions, managerial implications and limitations of this research.

\section{Review of Literature}

\subsection{Effectuation: Decision-making heuristics}

Heuristics provides a practical approach through which managers apply rules of thumb to aid decision making in situations of uncertainty (Grandori, 2010; Guercini, 2019). Prior work by Guercini, La Rocca, Runfola, and Snehota (2015) considered use of heuristics within buyer-seller relationships and posited heuristic rules that are used by salespeople when preparing for and engaging in face-toface meetings with a buyer. These are adaptation rules to identify and configure communications to match the business operations, role and position, personality and cultural background of their buyer, reacting rules to keep attention focused on the meeting, use of improvisation and time breaks to enable adaptation of the conversation should unexpected topics arise, and code of conduct rules used to ensure that respect is shown and personal bonds and build trust developed between the parties (Guercini et al., 2015). Yet, buyer-seller relationships are by their nature dyadic, with no claim that the rules used by salespeople are used by buyers. This therefore suggests further investigation is required to identify if and what heuristic rules buyers may use when making decisions. 
Effectuation theory, which is a combination of decision making heuristics, seeks to explain how decisions are made under uncertainty (Sarasvathy, 2009; Christopher Welter \& Kim, 2018). This contrasts with causal decision making, where goals are identified and then the resources and actions acquired to achieve the goals. Under effectual decision making, personal means (both possessed and acquirable), skills and knowledge are combined to create an opportunity or solution (Sarasvathy, 2009).

When applied to buying decisions, causal thinking suggests large firms identify required resources and then acquire them based upon predicted needs (Ivens \& Pardo, 2007). Needs appear to be market driven and customer focused, with clearly identified goals strategically aligned to the business (Cooper, 2018). Unplanned events are unwelcomed risks and, where closer collaboration with suppliers would be advantageous, more formal partnerships may be formed (Hakansson, Ford, Gadde, Snehota, \& Waluszewski, 2009).

In contrast, McGowan (2018) posits that when making buying decisions, owner-managers instead use the heuristics of effectual logic, which comprises means, partnership, affordable loss and leverage contingency (Christopher Welter \& Kim, 2018). Effectual means are the resources of 'who I am', 'what I know' and 'who I know' (Sarasvathy, 2001a, p. 78). This may enable an owner-manager to draw upon their social capital in order to access resources from suppliers within their network so as to promote flexibility and adaptiveness (Felzensztein, Brodt, \& Gimmon, 2014; Sarasvathy, 2009). Effectual partnership is the desire and ability to develop opportunities and share risk (Sarasvathy, 2009) with self-selecting partners (McKelvie, Chandler, DeTienne, \& Johansson, 2019; C. Welter, Mauer, \& Wuebker, 2016), thus enabling an owner-manager to co-create emergent solutions within pre-trusted relationships (McKelvie et al., 2019; C. Welter et al., 2016). Effectual affordable loss is the sum of time and money available to the owner-manager that may be lost without causing the absolute failure of the venture (Sarasvathy, 2009), thus enabling an owner-manager to enter into flexible supply relationships that limit risk to that which is affordable (Dew, Sarasvathy, Read, \& Wiltbank, 2009). Effectual leverage contingency is the ability to welcome problems and make rapid changes based upon uncertain circumstances (Sarasvathy, 2009), thus enabling an owner-manager to access a greater level of opportunity, for example, to supply to customers who require products and.

\subsection{Supplier relationships}

A comparison of the decision-making criteria used by large and micro firms is considered as it relates to buyer-supplier relationships and the constructs of buying activities, supplier selection and performance expectations, and make or buy decisions. 


\subsubsection{Personal relationships}

The role of personal relationships within the context of the buyer-seller dyad has been investigated in respect of strategic alliances, network innovation (Agostini \& Nosella, 2019) and internationalisation (Agostini \& Nosella, 2019; Brache \& Felzensztein, 2019; Felzensztein, Deans, \& Dana, 2019). Furthermore, work to identify the processes within such relationships, suggests relationship quality is dependent upon interaction, perceived relationship orientation, competence, benevolence (Casidy \& Nyadzayo, 2019), trust (Akrout \& La Rocca, 2019; Casidy \& Nyadzayo, 2019) and a willingness to customise (Nyadzayo, Casidy, \& Thaichon, 2020) Yet, while it would appear that such relationships are important to the development and success of a micro firm (La Rocca, Perna, Snehota, \& Ciabuschi, 2019), further work to identify the antecedents and efficacy of decision making heuristics, in respect of personal buyer-seller relationships is required (Guercini et al., 2015; Hesterly \& Smith; McGowan, 2018, 2020).

\subsubsection{Buying activities}

Extant literature suggests that, due to a lack of resources, an owner-manager may have to take personal control of buying activities (Ellegaard, 2009). Yet such control may offer control of input costs, avoidance of mistakes and facilitation of closer management of the overall profitability of their firm (Ellegaard, 2009; McGowan, 2018). It may also provide a way to maintain and develop personal and business relationships, thereby expanding their effectual means (Sarasvathy, 2009).

Owner-managers appear to prioritise buying activity directed towards helping their organisation meet immediate customer needs (Kavak, Tunçel, \& Özyörük, 2015b; Quayle, 2002). This could include developing relationships with suppliers' salespeople or senior managers through networking to build tacit knowledge about available products and services as well as trust, conceptualised as confidence (Ellegaard, 2009) developed through mutual respect, shared social experience and ethical alignment (Morrissey \& Pittaway, 2004).

Indeed, this investment in supplier relationships would appear directed toward developing a network of trusted suppliers who are prepared to be flexible and can offer a depth of resources that an owner-manager can call upon to provide more and better products and services to their customers and, should things go wrong, access to the backup and support needed to resolve their customers' problems (McGowan, 2018). All of this leads to:

Proposition 1: The owner-manager of a micro firm will take personal control of buying decisions so as to develop personal relationships that, in turn, lead to supplier flexibility. 


\subsubsection{Supplier selection and performance expectations}

Large firms use both formal buying criteria (Adams, Davis, Stading, \& Kauffman, 2013; Kraljic, 1983) to plan and acquire resources (Ivens \& Pardo, 2007) by scanning the whole market (Seung-Kuk et al., 2009) and agreements in which risks are transferred to the supplier (Seung-Kuk et al., 2009). In contrast, owner-managers of micro firms appears to prefer informal relationships that offer flexible buying arrangements (McGowan, 2018).

Supplier flexibility includes a willingness to adapt the sales and relationship offer, product and service quality, and availability of logistical, technical and other backup services (Cambra-Fierro \& Polo-Redondo, 2008; Ellegaard, 2009; Kavak et al., 2015b; Seung-Kuk et al., 2009; Weitz, Castleberry, \& Tanner, 2011; Wynarczyk \& Watson, 2005) so that should things go wrong, the supplier can be called upon to put them right (Cambra-Fierro \& Polo-Redondo, 2008; Ellegaard, 2009; Kavak et al., 2015b; Seung-Kuk et al., 2009; Wynarczyk \& Watson, 2005). This suggests that because supplier flexibility reduces the level of resources an owner-manager requires within their micro firm, it is more important than achieving the lowest price (McGowan, 2018).

A lack of scale and uncertainty of customer needs suggests a predilection toward flexible contract terms that avoid commitment by an owner-manager to delivering pre-determined levels of business within agreed timescales (Beekman \& Robinson, 2004; Ellegaard, 2009). This also suggests that when uncertainty or risk are perceived, supplier flexibility becomes a more important buying criterion than price alone (Bordonaba-Juste \& Cambra-Fierro, 2009; Morrissey \& Pittaway, 2006).

In summary, supplier flexibility facilitates risk management. By using trusted suppliers who offer flexible backup and support and limiting financial exposure to that which is affordable, with needs based only upon current customer requirements (McGowan, 2018), flexibility positively impacts supplier sales price (McGowan, 2018). All of this leads to:

Proposition 2: Supplier flexibility positively impacts the price that a micro firm ownermanager will be prepared to pay.

\subsubsection{Make or buy decision}

The decision of what to make internally and what to buy from suppliers sets the boundaries of the firm (Gadde \& Wynstra, 2018). The causal approach taken by a large firm includes understanding market needs and setting clear customer goals, with strategic alignment to overall business (Cooper, 2018). Marketing strategy includes segmentation, prioritisation and targeting, with a salesforce organised around selling models and channels, all with clearly defined objectives (Cron, Baldauf, Leigh, \& Grossenbacher, 2014; Panagopoulos \& Avlonitis, 2010; Terho, Eggert, Haas, 
\& Ulaga, 2015). Sales forecasts are thus translated into operational requirements (Johnston \& Marshall, 2016), with internal resources identified and those that are not readily available acquired from suppliers (Ivens \& Pardo, 2007). Thus, the sales organisation is tasked with selling what the firm can deliver.

An owner-manager of a micro firm is less able to plan for the nature and volume of future sales with barriers to success, including lack of infrastructure, organisation and process (Boejgaard \& Ellegaard, 2010; Dibb, Simkin, \& Wilson, 2008; Homburg, Droll, \& Totzek, 2008; Sharma, 2007). Use of effectual logic would, therefore, suggest the owner-manager identify potential customers to whom they can sell, determine customer needs and then, through their effectual means, access resources from their supplier network so as to customise a solution (Sarasvathy, 2009). This use of effectual selling appears to be dependent upon an effectual buying strategy. Thus, the ownermanager of the micro firm must continue to expand their supplier network because, should a customer require something they do not currently have available to them, the owner-manager may use their personal and business relationships to find a supplier who offers what is required along with the flexibility needed to meet the needs of their customer. All of this leads to:

Proposition 3: Use of effectual means (including effectual buying) to create individual customer solutions so as to secure sales orders will positively promote effectual selling, which may, in turn, also lead to the further use of effectual buying.

The relationships suggested by the above propositions are presented as a conceptual model in Figure 1. This suggests that supplier flexibility appears to be dependent upon personal relationships developed through the owner-manager taking personal control of buying activities (Ellegaard, 2009). Supplier flexibility appears to moderate price, as it would appear that supplier backup and support offers effectual means through which the owner manager can deal with problems without negatively impacting their customer relationships (McGowan, 2018). This leads to the overall buying outcome. As the sum of what can be bought will ultimately impact what can be sold (Hakansson et al., 2009) it is proposed that the use of an effectual buying strategy by an ownermanager may thus lead to an effectual selling strategy. Indeed, when an owner-manager identifies an opportunity that they are unable to fulfil through their existing means, they may well utilise their effectual buying skills to identify a supplier through which the means can be accessed to maximise their selling opportunity. 


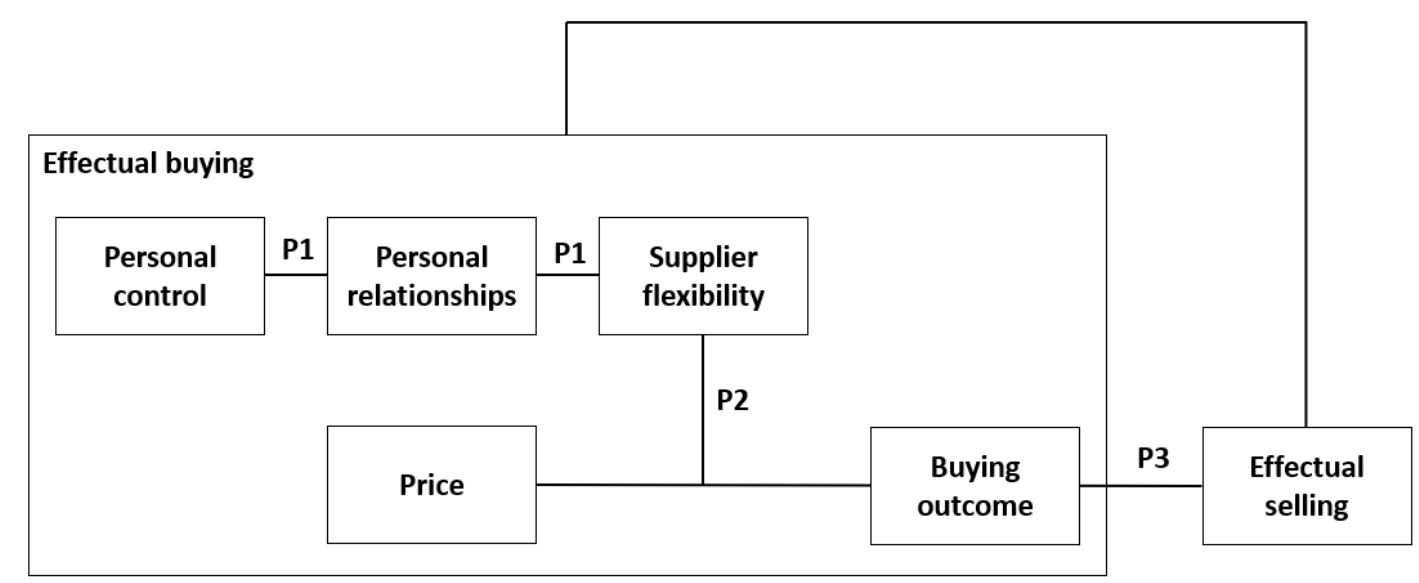

Figure 1: The relationship between effectual buying and selling.

\section{Methodology}

\subsection{Research perspective}

This study investigated how and why an owner-manager of a micro firm makes buying decisions. It was designed to be in line with other recent studies into the use of effectual logic (Hauser, Eggers, \& Güldenberg, 2019; Pfeffer \& Khan, 2018), is qualitative in nature and follows an interpretivist paradigm (Saunders, Lewis, \& Thornhill, 2012). The ontological position assumes reality is constructed through the experience of the life lived and the meaning participants make of it (Seidman, 2013).

This study provides a snapshot concerned with the variance of why and when an ownermanager of a micro firm may select effectual decision-making logic. The unit of analysis is the individual and the domain is their buying activities; boundary conditions are established firms that have been trading for more than 3.5 years (McKelvie et al., 2019; Oumlil \& Balloun, 2017).

In order to investigate the impact of effectual logic on buyer-seller relationships, it was important to identify a sector in which effectual buying would be a logical strategy, at least by the micro firms that operate in it, and in which the customers value other aspects of the relationship above price, for example, the skills and abilities of the provider or technical support. Extant literature suggested that the telecommunication sector would appear to be such a sector; due to the technical nature of the products, customers use constructs other than price to determine the selection of their supplier (Badri Ahmadi, Hashemi Petrudi, \& Wang, 2017; Yang, 2015). Thus, by selecting participants operating in a single market, other extraneous factors were minimised (Saunders et al., 2012). 


\subsection{Sample}

Prior work in relation to buying by Ellegaard (2009) suggested that owner-managers take personal control of buying decisions. Yet, in his paper, a small firm is defined as employing fewer than 20 people. While ensuring that his sample contained only firms where the owner-manager is in day-to-day control, this size classification does not align with the recognised definition of a small firm. The European Union does, however, provide some useful definitions for Small- and MediumSized Enterprises (SMEs), with a small firm having between 0-49 employees and/or turnover of less than €50M ("What is an SME," 2005). While it may be that owner-managers of a firm at the lower end of this scale may take personal ownership of buying decisions, it would seem plausible that firms at the upper end of the scale may employ staff to engage in buying activities. This suggests that the European Union's definition of a micro firm as having fewer than 10 staff and/or turnover less than $€ 2 M$ ("What is an SME," 2005), was the most appropriate measure for this study.

Purposive homogeneous sampling was used to identify participants (Creswell \& Poth, 2016; Saunders et al., 2012). Initial internet searches for 'telecommunication resellers UK' and 'telecoms resellers UK' produced a long list of potential participants. Financial accounts were downloaded from UK Companies House and inspected to identify those that matched the sample criteria. The ownermanager was then approached by telephone and invited to participate in a telephone interview. On average interviews were 33 minutes in duration. A summary of participants is shown in Table 1.

Table 1: Summary of participants

\begin{tabular}{|c|c|c|c|c|c|c|c|c|c|c|c|c|}
\hline 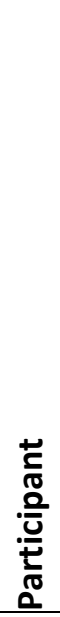 & 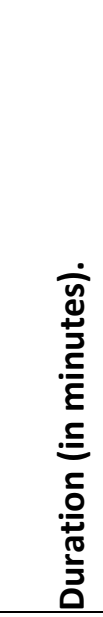 & 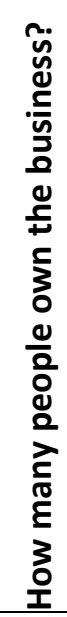 & 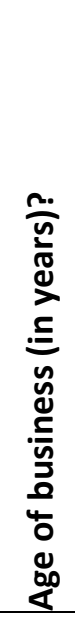 & 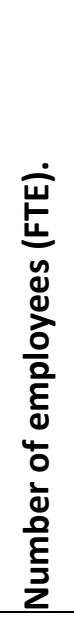 & 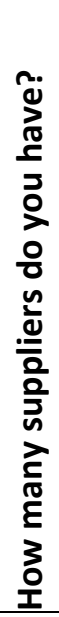 & 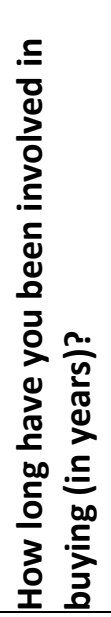 & 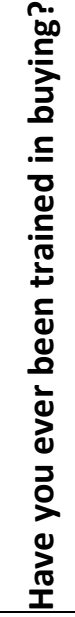 & 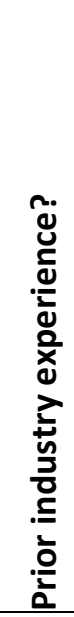 & 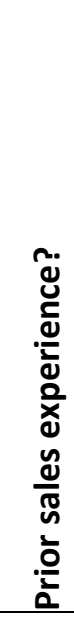 & 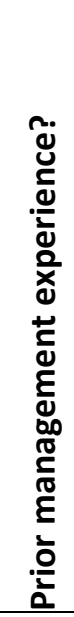 & 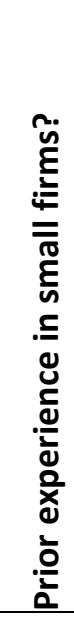 & 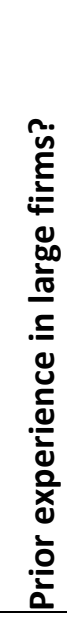 \\
\hline 1 & 22 & 1 & 19 & 8 & - & 33 & No & Yes & Yes & Yes & No & Yes \\
\hline 2 & 37 & 3 & 5 & 2 & 10 & 5 & No & Yes & Yes & Yes & Yes & Yes \\
\hline 3 & 38 & 2 & 13 & 3 & 30 & 30 & No & Yes & Yes & Yes & Yes & Yes \\
\hline 4 & 45 & 2 & 16 & 2 & 9 & 16 & No & Yes & Yes & Yes & No & Yes \\
\hline 5 & 37 & 1 & 7 & 7.5 & 6 & 10 & No & Yes & Yes & Yes & Yes & Yes \\
\hline 6 & 46 & 2 & 9 & 8 & 14 & 9 & No & Yes & Yes & Yes & No & Yes \\
\hline
\end{tabular}




\begin{tabular}{|r|c|c|c|c|c|c|c|c|c|c|c|c|}
\hline $\mathbf{7}$ & 25 & 2 & 27 & 9 & 8 & 27 & No & Yes & No & No & No & Yes \\
\hline 8 & 20 & 2 & 18 & 6 & 30 & 18 & No & Yes & Yes & No & No & Yes \\
\hline 9 & 38 & 3 & 8 & 5 & 10 & 6 & No & Yes & No & No & No & Yes \\
\hline 10 & 30 & 2 & 9 & 3 & 12 & 9 & No & Yes & Yes & Yes & Yes & No \\
\hline 11 & 39 & 1 & 8 & 4 & 20 & 8 & No & Yes & No & Yes & No & Yes \\
\hline 12 & 28 & 2 & 16 & 2 & 20 & 16 & No & Yes & No & Yes & No & Yes \\
\hline 13 & 30 & 2 & 25 & 2 & 8 & 25 & No & Yes & No & Yes & No & Yes \\
\hline Average & $\mathbf{3 3}$ & $\mathbf{2}$ & $\mathbf{1 4}$ & $\mathbf{5}$ & $\mathbf{1 5}$ & $\mathbf{1 6}$ & & & & & & \\
\hline Total & & & & & & & $\mathbf{0}$ & $\mathbf{1 3}$ & $\mathbf{9}$ & $\mathbf{1 0}$ & $\mathbf{4}$ & $\mathbf{1 3}$ \\
\hline
\end{tabular}

\subsection{Interview guide}

An interview script linking questions to literature and casual or effectual decision making was developed (McKelvie et al., 2019). Apart from questions regarding the participant's, business situation (ownership, age, number of full time employees (FTE) and number of suppliers) and personal experience (industry, firm size, management, buying and selling), the interview guide was based upon the following questions (with number of prompts shown in brackets):

Q1: Can you talk me through how you choose suppliers? (10).

Q2: How would you describe your relationship with your most important suppliers? (8).

Q3: Do you work in partnership with any of your suppliers to create new marketing initiatives, products or services? (4).

\subsection{Data analysis}

Semi-structured recorded telephone interviews were conducted during December 2019, transcribed verbatim and analysed thematically using the Braun and Clarke (2006) six-stage process. Data was organised in NVivo software. Sixty researcher-derived initial codes were generated (Braun \& Clarke, 2013). Codes were collated into seven initial themes, then applied to an a priori coding template based upon the propositions in this paper and findings from McGowan (2018). A recursive approach was taken to allow for additional codes and themes to be created and included in the analysis up to completion of the project. After 13 interviews, theoretical saturation appeared to have been reached, as participants were no longer providing new information (Creswell \& Poth, 2016; Saunders et al., 2012). 


\section{Findings and discussion}

Data acquired during 13 semi-structured interviews with owner-managers of micro firms was thematically analysed using both open and a priori coding (Braun \& Clarke, 2013). Figure 2 shows the relationships between themes, sub-themes and individual codes, compared by the number of coding references, at phase six of the analysis process (Braun \& Clarke, 2006).

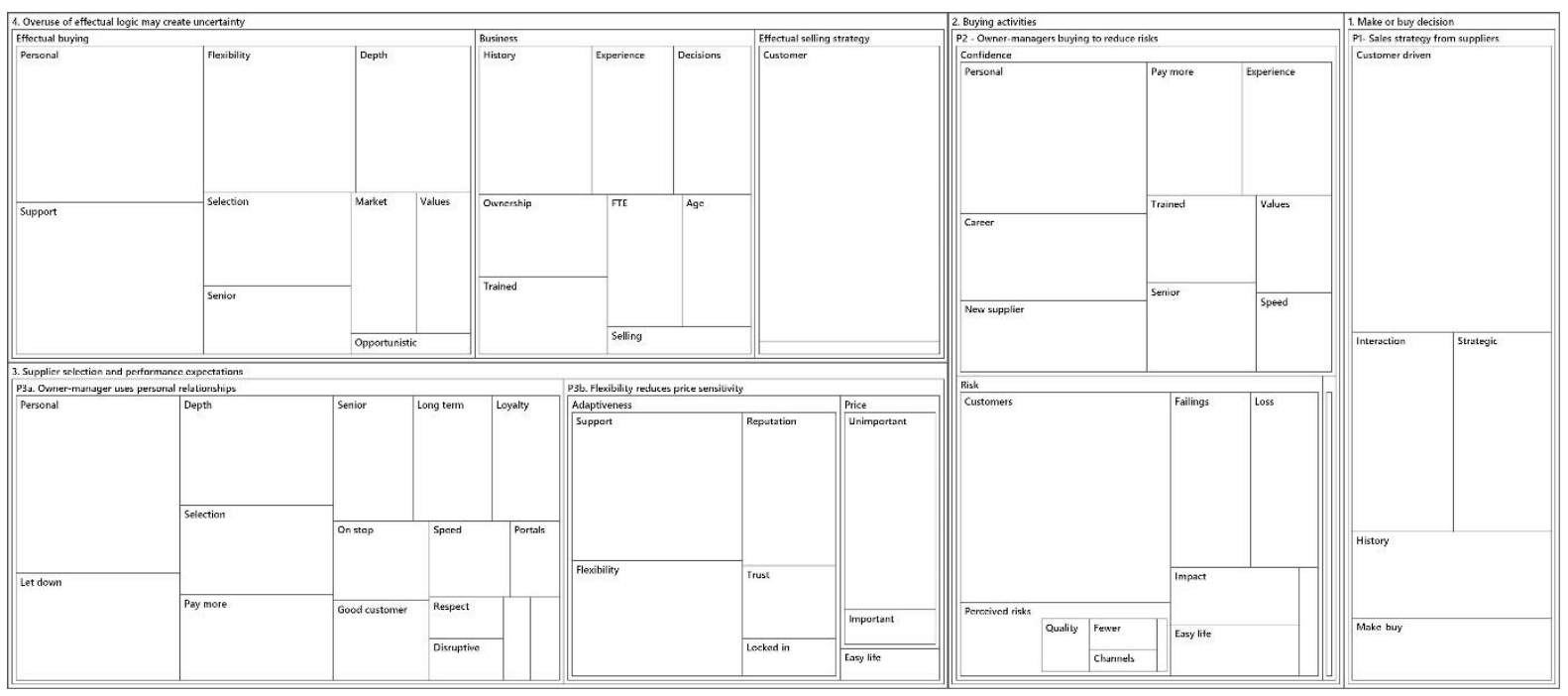

Figure 2: Nodes and themes compared by number of coding references, at phase 6 of the coding process (Braun \& Clarke, 2006)

Findings are first presented in relation to the propositions of this paper, followed by introduction of a new theme identified through the data analysis and consequent conceptual model, which suggests that effectual buying and effectual selling may increase the level of uncertainty experienced by the owner-manager of a micro firm.

\subsubsection{Buying activities}

None of the participants had been formally trained in buying, yet 11 had significant experience in a sales or sales management role and two participants had experience in customer support, suggesting experience in meeting customer needs and the implications when a firm does not. Most participants said that they had been involved in buying since the inception of their firm, which is in line with the suggestion that owner-managers were untrained in buying, yet have a predilection to handle it personally (Ellegaard, 2006). Indeed, participants gave the impression that, as experienced businessmen with experience in selling and customer service, they possessed tacit knowledge (Jisr \& Maamari, 2017) and, therefore, did not need formal training in buying. Participant 7 (P7) joked about it: 'Yes, my wife taught me [when] buying Jimmy Choo shoes and handbags (Laughter)'. This link between selling and buying skills was expressed well by P5: 'It's similar to sales where you need to speak to a guy that can say, "Yes."... it's the same with talking to a supplier.' 
When asked how new suppliers were selected, participants talked about interpersonal relationships (Morrissey \& Pittaway, 2004). 'Over the years I've built up contacts... the telecoms support company we use is somebody that I have probably known for 20 years' (P10). Similarly, '...niceness... I actually get on really well with the guy. We have a chuckle on the phone, he knows what he's talking about, gives me all the right answers..., the price is right, the product is right, I like him, so I will deal with his company' (P11). The way in which participants talked about the role of personal relationships suggests interaction, competence, benevolence (Casidy \& Nyadzayo, 2019; Nyadzayo et al., 2020) and trust (Akrout \& La Rocca, 2019), all of which lead to a high quality buyerseller relationships (Casidy \& Nyadzayo, 2019; Nyadzayo et al., 2020). Furthermore, the way that P10 discussed use of humour by both buyer and seller, appears to be consistent with use of adaptation heuristics, in which the seller configures their communication to suit the role, position and personality of the buyer, reacting heuristics in which the seller responds to events as they unfold and code of conduct heuristics in which respect and personal bonds are antecedents to trust development between the parties (Guercini et al., 2015).Participants discussed they dealt with a new supplier by requiring them to prove themselves, often by providing a trial sample. When talking about how he brought on board a new product, P1 said 'I tread carefully. Make sure you know what you're doing and you're working with a supplier that has a track record'. Similarly, 'I do as much checking as I can in the first place to make sure it does what it says on the tin' (P13). This cautious approach also applies to existing suppliers. 'When a new product or a new service comes out, even if it is with one of our trusted suppliers, we won't go all guns blazing. We'll try it ourselves and let them make the mistakes, because they will. They'll get things wrong, as everybody does when a new service comes out... we very much dip our toe in the water' (P4). All of this suggests that ownermanagers of micro firms understand the importance of interaction between their suppliers and their own ability to deliver to their customers (Hakansson et al., 2009).

Personal control of buying appears to allow an owner-manager to control the quality of the solution that they deliver to their end user customers. This was expressed particularly well by P10, 'It's our reputation with the end user that is at stake, the [customer] end user won't necessarily know who is behind us in a network, so if something goes wrong, we get our backsides kicked, and it's our reputation that gets damaged, not the people sitting behind us', suggesting that interaction between supplier performance and the overall performance of the micro firm (Hakansson et al., 2009) is a significant consideration for owner-managers when making a buying decision. Indeed, this need for the supplier to provide flexibility in the form of backup and service so that, should things go wrong, the owner-manager can call upon them to resolve the problem, appears to significantly impact the basis of the buying decision. This provides support for proposition 1 , which states that a micro firm 
owner-manager will take personal control of buying decisions so as to develop personal relationships that, in turn, lead to supplier flexibility. The importance of flexibility is further discussed in relation to price, as it would appear that the more capable and willing a supplier is to provide flexibility of backup and support, the less importance an owner-manager will assign to price (McGowan, 2018).

\subsection{Supplier selection and performance expectations}

When talking about other factors impacting supplier selection, all participants were prepared to pay more for products and services from a supplier that provided support and flexibility (McGowan, 2018). 'What I'm looking for is... how quickly can I get support? Who does the support and what's the sales order process and how quickly can I get a sales order satisfied, and so on?... Cost comes, probably, third, fourth and even fifth on that list.... sometimes you can tell by the tone of voice what they're saying, how they're saying [it], and whether they're going to be reliable or not' (P5). Put perhaps, more succinctly, 'it's all to do with service, how reactive and ... suppliers showing that they care about us a customer' (P9).

The way in which participants discussed day-to-day operations suggested that suppliers are of strategic importance. Indeed, there is a tacit understanding that the abilities of their firm are dependent upon their suppliers, as they provide access to resources which enable the firm to meet its customer's needs (Agostini \& Nosella, 2019; Hakansson et al., 2009; Jisr \& Maamari, 2017). All participants made comments similar to these: 'if they're not there, there is no business' (P1); 'yes, without a doubt [our suppliers are strategic]' (P4); and 'we couldn't do [business] without them' (P9). Indeed, the participants felt strongly that their suppliers needed to view them as good customers: 'We're a good company to deal with... we have good technical experience, so know all the products that we're selling well and, commercially, we are a good credit risk' (P1). Similarly, 'If a supplier put us on stop, I would consider that being our failing. We would have done something wrong' (P4). This suggests that an owner-manager of a micro firms desires high quality relationships (Akrout \& La Rocca, 2019; Casidy \& Nyadzayo, 2019) and is prepared to commit to being good a customer, as they appear to recognise the value of their suppliers to extend the capability of their firm and its ability to secure new business and meet its obligations to its customers, in alignment with the concept of IMP Interaction as posited by Hakansson et al. (2009). Indeed, the implications of a supplier failure were stark: 'you lose business partnerships, you lose business and, worst case, have to reverse deals altogether' (P1). Additionally, supplier failure can impact the overall profitability of the micro firm. 'That [supplier failing] had an impact on us not only because of the outage and the time to fix [for our customers], but we couldn't bill any of our customers for about a day [worth of phone calls] either and that came straight out of the bottom-line of our business' (P11). Accordingly, from the 
perspective of the micro firm owner-manager, supplier relationships need to be interpersonal, not interfirm. P6 said 'when I have a problem, I raise it with [name] in the [suppliers] management team... to make sure [my customer's problem] gets progressed'. Seniority also appears to be important: 'If I want something doing and I want it doing quickly, I speak to the person that can say, "Yes," and they do it' (P5).

In return for access to flexibility and support, the participants appear to offer customer loyalty. It would seem that a supplier having a problem would but necessarily cost them future business. P11 said, 'it's not what you do, it's how you deal with it... not necessarily what you say but how you say it... how you fix it and how you deal with it, that makes a big difference to me'. Similarly, 'I wouldn't sever the relationship. I would try and think about how I can protect myself from my customer's point of view' (P12), suggesting a desire to continue working with the supplier but to understand their weaknesses and mitigate them so as to protect the end customer. Yet, there are limits, as suggested by P7: 'when I have a problem, I scream and scream and scream... put a black mark against them. It depends how much they'd screwed up and how badly it affected us. If it wasn't too major, we'll just bear it in mind, but if they really kept screwing up, I would immediately start seeking an alternative'. A similar approach was discussed by P10: 'If they mess up, we'll raise it with them and if they mess up twice then we start looking elsewhere'. This suggests the relationships that an owner-manager has with individuals within their suppliers is of prime importance to them. P12 explained how he had ceased to use one supplier due to changes in the business and the people with whom he was dealing. 'I've kicked service suppliers [out] because [the] people [we dealt with] have gone, and I [now] don't feel comfortable with them, so l've stopped using them'.

In summary, price of the products or services appears not to be the most important factor in the supplier selection and buying decisions made by the majority of the micro firm owner-managers who participated in this study. Participant 3 provided an explanation that was echoed by many of the other participants when he said, 'we don't buy just on price.... it is the support that goes with it. We have an example of that right now, where the support on a handset and software combination is better from one supplier than the other. Even though we might pay a few pounds more, now and again, for handsets from the better one, we'll stay carry on buying from them, because the support is better'.

Yet not one of the participants said that they would engage in long term supply contracts' instead, flexible buying arrangements are required. P2 explained what long-term commitments might look like in their industry and why he would not enter into one 'I don't have a long-term supply contract with any of my suppliers. It's not like I'm committed to buy from them for a year, two 
years or three years. It's a flexible supply chain. So, I can pick and choose as to where I get products from on a day to day, week to week, month to month basis. I wouldn't sign with a supplier if they said, "Well, we must have all your business for 3 years". Participant 10 explained that he felt that the size of the company precluded him from entering into long-term buying commitments: 'No, we don't do targets. I think because of the size of the company, we can't commit to any target'. This suggests that while the owner-managers of micro businesses consider relationships to be long term, their lack of scale and uncertainty about future customer needs precludes them from entering into long-term buying contracts.

P2 captured the essence of the situation that owner-managers of micro firms face when selecting suppliers and the decision-making logic that is used when he reported on a conversation he had with a friend who was thinking of starting his own business:

If you go and buy a phone from that [supplier] and something goes wrong with that phone, it takes you two weeks to sort it out. Reputationally, the damage is to your business because you didn't go with a better supplier at $f 5$ or $f 10$ more, but because it was cheap and it was quick, but then they can't support you because there's no margin in it [for them], so you've made the wrong decision. So, questions that you should be asking are, "What do you want from your supplier? Do you want price? Do you want products? Do you want service? Do you want support? Do you want a good returns management process?" You want all these things. Because if something goes wrong then you need to send it back for repair or replacement and that can take months. So, you need to really find out, from that supplier, what they're going to do for you, based on what you need to provide your customers. That, to me, has always been so obvious when working with suppliers, yet so many people out there say, "Oh no, I couldn't be bothered with that. I'm going to buy those handsets for $f 5$ cheaper from here or 110 cheaper from there, " or whatever the device is. I just look at them. I mean, "Are you mad? I know the company you're thinking about going to work with and they've got a poor reputation for support. You might think that's okay, but when your customer's moaning at you, well, it's a different subject, isn't it?"'

All of this supports proposition 2, which states that supplier flexibility positively impacts the price that a micro firm owner-manager will be prepared to pay.

\subsection{Make or buy decision}

The participants in this study are resellers: '[our] business is reselling ... We couldn't start our own network; it wouldn't be cost advantageous to do that... it's taken [our suppliers] millions [of pounds] to create these phone systems' (P6). Indeed, there would appear to be no formalised, planned buying strategy; instead, the buying requirements relate only to the customers with whom 
the micro firm is currently transacting: 'we get the product that best suits that customer's needs' (P2). Similarly, (P9) stated: 'I did a deal last month for a customer that used a certain brand of [telephone system] and it's not something our engineers are trained on, so it just got farmed out to a company that we know well'. This suggests that the micro firm borders on being a virtual enterprise in which the personal involvement in buying creates for the owner-manager a way to maintain and further develop personal and business relationships with current and potential suppliers, thus increasing their overall effectual means, which are subsequently applied to creating and fulfilling sales opportunities for their micro firm (Sarasvathy, 2009), thus supporting proposition 3, which states that use of effectual means (including effectual buying) to create individual customer solutions so as to secure sales orders will positively promote effectual selling, which may, in turn, also lead to the further use of effectual buying.

\subsection{Use of effectuation leads to increased uncertainty}

As aforementioned, an owner-manager of a micro firm may utilise an iterative process when engaged in buying and selling so as to match the needs of a customer with the capabilities of a supplier (Hakansson et al., 2009). This was articulated by P4: 'We were looking to provide a fully hosted system, but... they [wanted] tablets... a multimedia system. We don't provide that ... I've had a look around [at our suppliers] to see if we can get that type of service, but it's not our main business'. This suggests that the owner-manager appears prepared to deliver anything the customer may request, subject to being able to apply their effectual means to identify a supplier that offers the flexibility and backup to minimise risk to the point of affordability (McGowan, 2018). In short, the selling strategy appears to be effectual. This use of effectual selling appears to positively impact the ability of the owner-manager to win more business. Yet, effectual selling does appear to reduce the ability to forecast customer demand, thus preventing use of a formalised, causal, buying strategy. As needs are uncertain, an effectual buying strategy is required to meet the needs created by the effectual selling strategy. Thus, an iterative process develops in which effectual buying leads to the ability to engage in effectual selling, which, in turn, leads to an uncertainty of needs, thus requiring an effectual buying strategy, as illustrated in Figure 3.

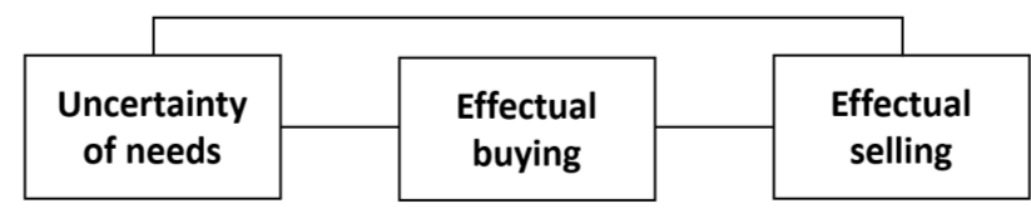

Figure 3: The impact of effectual buying and selling 
While use of effectual logic is posited as a way to reduce uncertainty so as to enable an owner-manager of a micro firm to make decisions (Sarasvathy, 2009), the findings of this study suggest that using effectual logic to make buying and selling decisions appears to create, rather than reduce, the uncertainty experienced by owner-managers of micro firms.

\section{Conclusion}

This study considered the decision-making processes of owner-managers of established micro firms. Findings suggest that a micro firm owner-manager may apply effectual logic when making a buying decision (Sarasvathy, 2009); specifically, through the personal control of buying activities they develop effectual means through personal relationships with trusted suppliers (McGowan, 2018; Sarasvathy, 2009). Furthermore, it suggests that heuristics adaptation, reacting and code of conduct rules used by sales people (Guercini et al., 2015) appear to facilitate high quality relationships (Akrout \& La Rocca, 2019; Casidy \& Nyadzayo, 2019; Guercini et al., 2015), that are valued by owner-managers of micro firms as such relationships positively promote supplier flexibility, which is operationalised as the provision of support and backup that is applied to resolve problems should things go wrong. As the level of supplier flexibility minimises loss potential to that which is affordable (Dew et al., 2009), the owner-manager is therefore willing to pay more for the products and services that they buy (McGowan, 2018).

From an IMP perspective, this study further extends the findings of previous work into buyer-seller interaction (Agostini \& Nosella, 2019; Casidy \& Nyadzayo, 2019; Guercini et al., 2015; Hakansson et al., 2009) by identifying the importance of inter-personal relationships to ownermanagers of micro firms and their recognition of the importance of suppliers to their ability to win new business and deliver to their customers' expectations (Hakansson et al., 2009). Indeed, it would appear that for the firms that participated in this study, their business model was so aligned with their suppliers that should a relationship fail, it could potentially cost them both short term business and impact their long term success (Hakansson et al., 2009). Yet, while the importance of long term supplier relationships appears to be understood and valued by owner-managers, they were not, however, willing to participate in long term contractual supply agreements. This suggests that owner-managers of micro firms recognise that they operate within a situation of uncertainty and, it would appear, that they do indeed apply the heuristics of effectuation (Sarasvathy, 2009; Christopher Welter \& Kim, 2018), when determining buying decisions (McGowan, 2018).

Furthermore, application of effectual logic to buying decisions appears to positively promote use of effectual selling, thus enabling the owner-manager to match customer requirements in real time to that which they have or can access from suppliers. This creates an ongoing iterative process, 
in which effectual selling leads to effectual buying. In contrast to extant literature, which states that effectuation is a way to reduce uncertainty to a level at which a decision can be made (Sarasvathy, 2009), the findings of this study suggest that application of effectual logic to buying and selling decisions can instead create, rather than reduce, uncertainty.

\section{Managerial advice}

This study appears to show that use of effectual buying and effectual selling logics appears to increase, rather than reduce, the level of uncertainty experienced by the owner-manager of a micro firm. Accordingly, advice is directed toward reducing this uncertainty.

Effectual buying and selling appears to provide a micro firm the ability to engage with flexible suppliers so as to offer a heterogeneous array of products and services to its customers, thus promoting sales success. Yet, the lack of homogeneity of customer needs and requirement for supplier flexibility may well lead to overall costs greater than those that could be achieved if the micro firm specialised range of products and services and developed internal resources to deliver these to its customers.

Literature delineates between buying and selling activities; while these are opposite sides of a dyadic relationship, they are operationalised using different skills and techniques. None of the owner-managers who participated in this study had been trained in buying (Ellegaard, 2006, 2009) or, perhaps more importantly, appeared to see the relevance of such training. Yet extant literature would suggest that planned and formalised casual buying (Adams et al., 2013; Seung-Kuk et al., 2009) by professional, trained buyers (Ellegaard, 2006, 2009) would offer a range of business benefits. Similarly, from the perspective of selling, there is a significant body of literature that offers advice with respect to sales strategy and sales management that extolls the benefits of a more formalised, causal approach to selling (Cron et al., 2014; Johnston \& Marshall, 2016; Panagopoulos \& Avlonitis, 2010; Terho et al., 2015). It is, therefore, recommended that the owner-managers of micro firms consider how best to develop the skills and resources needed to implement a more causal, less effectual, approach to both buying and selling so as to reduce uncertainty.

Furthermore, it would appear that reliance on supplier flexibility has the advantage of reducing overhead costs and allowing a more effectual approach to selling. Yet this does suggest that the price paid for the products and services may be greater than could be achieved if said resources were available within the micro firm (McGowan, 2018). It is, therefore, recommended that owner-managers of micro firms calculate the cost of internal resources vs the extra that is currently 
paid to suppliers for their willingness to be flexible, as this will enable a more nuanced approach to buying to be adopted.

All this leads to the suggestion that while effectual buying and selling may appear to be an attractive strategy to an owner-manager of a micro firm, it should be approached with caution as it may create an ever increasing cycle of uncertainty. Growth through effectual selling appears to necessitate an ever increasing requirement for effectual buying. As the ability of the firm to deliver upon its promises to its customers is reliant upon its suppliers, unless sufficient resources are developed within the micro firm to protect against supplier failure, should such a failure occur, it may negatively impact customer satisfaction, future sales and have a potentially negative impact upon future growth (Hakansson et al., 2009).

\section{Limitations}

One limitation of this study is that it is based upon single interviews with a sample of ownermanagers who operated established micro firms within the same industry. Furthermore, while findings appear to suggest the use of heuristics, by micro firm owner-managers, including some that appear to be similar to those in use by salespeople (Guercini et al., 2015), it may be that a deeper understanding of the phenomena may be achieved through use of ethnographic and / or more longitudinal methods of investigation (Guercini, 2019). Accordingly, findings and interpretations may not automatically be transferred to other organisational settings and future research should consider the methodological requirements for investigation of heuristics (Guercini et al., 2015).

\section{Future research}

This study has shown that, instead of planning for customer demand (Ivens \& Pardo, 2007), it is through identifying the best supplier from the whole market and building contracted arrangements in which risk is transferred to the supplier (Seung-Kuk et al., 2009) that an ownermanager of a micro firm would appear to use their effectual means to match customer needs and supplier capabilities in real-time. The benefits and instinctive use of IMP interaction to align customer needs with supplier capabilities (Hakansson et al., 2009), appears to enable ownermanagers of micro firms to sustain their businesses into the established phase (Oumlil \& Balloun, 2017), suggesting that such processes are, to some extent, successful. Yet, with an average firm age of 14 years, it is surprising that these businesses have failed to grow beyond being classified as micro ("What is an SME," 2005). This could, of course, be a function of the sampling strategy used for this study. However, it might be that continued use of effectual buying and effectual selling may, in fact, limit the ability of a firm to grow. This leads to a number of questions for future research. From a 
buying perspective, does using an effectual buying strategy, compared to a more formalised, causal one (Adams et al., 2013; Ivens \& Pardo, 2007; Seung-Kuk et al., 2009), impact the ability of the firm to grow, or to develop new products and services, or to achieve other forms of differentiation so as to further develop a sustainable competitive advantage? Additionally, is it just micro firms that engage in effectual buying, or could it be that it is utilised by firms of other sizes? Considering effectual buying from the other side of the dyad, how do suppliers view firms that engage in effectual buying and how best can a supplier organise itself to take advantage of that market opportunity?

Effectual selling may also have an impact on the growth of a micro firm. Future research into the impact of effectual selling on growth, giving consideration to efficacy at different stages in a firms journey from start-up to established, would be of interest. While in this study, micro firms were the primary focus, is or should effectual selling be used by firms of other sizes and, if so, is there is a point beyond which its continued use becomes detrimental to the overall success of the business?

Additionally, consideration could be given to investigating the impact of effectual buying and effectual selling on the end customer. Could a customer benefit from the ability of a firm to deliver everything they require through combined use of internal resources and their informal supplier network? Does effectual selling have any impact on the development of trusted relationships between the customer and seller? Finally, does effectual selling impact the ability of the supplier to close an order and, if it does, why?

Finally, as aforementioned, the way that owner-managers of micro firms talked about their decision making processes when determining buying decisions, suggests that they use the bundle of heuristics contained within effectuation theory (Christopher Welter \& Kim, 2018). Prior work with respect to the seller side of the buyer-seller dyad suggests that salespeople also use a range of heuristics when engaged in meetings with buyers (Guercini et al., 2015). Some, but not all of the heuristics used by salespeople were detected in this study (Guercini et al., 2015). This is unsurprising, as the heuristics used by salespeople was not the focus. Yet, it would be interesting to identify, then compare and contrast the heuristics used by salespeople against those used by micro firm owner-managers when determining buying decisions. Noting the methodological advice from Guercini (2019), consideration should be given to undertaking such work using longitudinal ethnographical studies. 


\section{References}

Adams, J. H., Davis, J., Stading, G., \& Kauffman, R. G. (2013). Achieving strategic supplier leverage for small enterprises by using purchasing development complexity. International Journal of Business, Marketing, \& Decision Science, 6(1), 72-87.

Agostini, L., \& Nosella, A. (2019). Inter-organizational relationships involving SMEs: A bibliographic investigation into the state of the art. Long Range Planning, 52(1), 1-31. doi:https://doi.org/10.1016/j.Irp.2017.12.003

Akrout, H., \& La Rocca, A. (2019). Interpersonal and Inter-organizational Trust in High-involvement Customer-Supplier Relationships: Antecedents, Consequences, and Moderators. In New Insights on Trust in Business-to-Business Relationships (Vol. 26, pp. 87-102): Emerald Publishing Limited.

Badri Ahmadi, H., Hashemi Petrudi, S. H., \& Wang, X. (2017). Integrating sustainability into supplier selection with analytical hierarchy process and improved grey relational analysis: a case of telecom industry. The International Journal of Advanced Manufacturing Technology, 90(9), 2413-2427. doi:10.1007/s00170-016-9518-z

Beekman, A. V., \& Robinson, R. B. (2004). Supplier partnerships and the small, high-growth firm: Selecting for success. Journal of Small Business Management, 42(1), 59-77. doi:10.1111/j.1540627X.2004.00097.X

Bocconcelli, R., Cioppi, M., Fortezza, F., Francioni, B., Pagano, A., Savelli, E., \& Splendiani, S. (2016). SMEs and Marketing: A Systematic Literature Review. International Journal of Management Reviews, 20(2), 227-254. doi:10.1111/ijmr.12128

Boejgaard, J., \& Ellegaard, C. (2010). Unfolding implementation in industrial market segmentation. Industrial Marketing Management, 39(8), 1291-1299. doi:10.1016/j.indmarman.2010.06.004

Bordonaba-Juste, V., \& Cambra-Fierro, J. J. (2009). Managing supply chain in the context of SMEs: A collaborative and customized partnership with the suppliers as the key for success. Supply Chain Management: An International Journal, 14(5), 393-402. doi:10.1108/13598540910980305

Brache, J., \& Felzensztein, C. (2019). Exporting firm's engagement with trade associations: Insights from Chile. International Business Review, 28(1), 25-35.

doi:https://doi.org/10.1016/i.ibusrev.2018.07.001

Braun, V., \& Clarke, V. (2006). Using thematic analysis in psychology. Qualitative Research in Psychology, 3(2), 77-101. doi:10.1191/1478088706qp063oa

Braun, V., \& Clarke, V. (2013). Successful qualitative research: A practical guide for beginners. London: Sage.

Bryman, A., \& Bell, E. (2015). Business research methods (4th ed.). Oxford, United Kingdom: Oxford University Press, [2015].

Cambra-Fierro, J. J., \& Polo-Redondo, Y. (2008). Long-term orientation of the supply function in the SME context. International Small Business Journal, 26(5), 619-646.

doi:doi:10.1177/0266242608094032 
Casidy, R., \& Nyadzayo, M. (2019). Drivers and outcomes of relationship quality with professional service firms: An SME owner-manager perspective. Industrial Marketing Management, 78, 27-42. doi:https://doi.org/10.1016/j.indmarman.2017.09.011

Cooper, R. G. (2018). The drivers of success in new-product development. Industrial Marketing Management. doi:10.1016/j.indmarman.2018.07.005

Creswell, J. W., \& Poth, C. N. (2016). Qualitative inquiry and research design: Choosing among five approaches: Sage publications.

Cron, W. L., Baldauf, A., Leigh, T. W., \& Grossenbacher, S. (2014). The strategic role of the sales force: perceptions of senior sales executives. Journal of the Academy of Marketing Science, 42(5), 471-489. doi:10.1007/s11747-014-0377-6

Davies, I. A., \& Ryals, L. J. (2014). The effectiveness of Key Account Management practices. Industrial Marketing Management, 43(7), 1182-1194. doi:10.1016/j.indmarman.2014.06.007

Dew, N., Sarasvathy, S. D., Read, S., \& Wiltbank, R. (2009). Affordable loss: Behavioral economic aspects of the plunge decision. Strategic Entrepreneurship Journal, 3(2), 105-126. doi:10.1002/sej.66

Dibb, S., Simkin, L., \& Wilson, D. (2008). Diagnosing and treating operational and implementation barriers in synoptic marketing planning. Industrial Marketing Management, 37(5), 539-553. doi:10.1016/j.indmarman.2007.08.002

Ellegaard, C. (2006). Small company purchasing: A research agenda. Journal of Purchasing and Supply Management, 12(5), 272-283. doi:http://dx.doi.org/10.1016/j.pursup.2006.08.004

Ellegaard, C. (2009). The purchasing orientation of small company owners. The Journal of Business and Industrial Marketing, 24(3-4), 291-300. doi:10.1108/08858620910939831

Felzensztein, C., Brodt, S. E., \& Gimmon, E. (2014). Do strategic marketing and social capital really matter in regional clusters? Lessons from an emerging economy of Latin America. Journal of Business Research, 67(4), 498-507. doi:https://doi.org/10.1016/j.jbusres.2013.11.006

Felzensztein, C., Deans, K. R., \& Dana, L. p. (2019). Small Firms in Regional Clusters: Local Networks and Internationalization in the Southern Hemisphere. Journal of Small Business Management, 57(2), 496-516. doi:10.1111/jsbm.12388

Fisher, G. (2012). Effectuation, causation, and bricolage: A behavioral comparison of emerging theories in entrepreneurship research. Entrepreneurship: Theory and Practice, 36(5), 1019-1051. doi:10.1111/j.1540-6520.2012.00537.x

Gadde, L.-E., \& Wynstra, F. (2018). Purchasing management and the role of uncertainty. IMP Journal, 12(1), 127.

Grandori, A. (2010). A rational heuristic model of economic decision making. Rationality and Society, 22(4), 477-504. doi:10.1177/1043463110383972

Guercini, S. (2019). Heuristics as tales from the field: the problem of scope. Mind \& Society, 18(2), 191-205. doi:10.1007/s11299-019-00221-4 
Guercini, S., La Rocca, A., Runfola, A., \& Snehota, I. (2015). Heuristics in customer-supplier interaction. Industrial Marketing Management, 48, 26-37.

doi:https://doi.org/10.1016/j.indmarman.2015.03.008

Håkansson, H., \& Ford, D. (2016). The managerial challenge of business interaction: behind the market façade. The IMP Journal, 10(1), 154.

Hakansson, H., Ford, D., Gadde, L. E., Snehota, A. W. I., \& Waluszewski, I. (2009). Business in networks. In. Chichester: John Wiley \& Sons.

Hauser, A., Eggers, F., \& Güldenberg, S. (2019). Strategic decision-making in SMEs: effectuation, causation, and the absence of strategy. Small Business Economics. doi:10.1007/s11187-019-00152-x

Hesterly, W., \& Smith, J. S. B. The Role of Heuristics in Alliance Collaboration for Entrepreneurial Firms. In The Oxford Handbook of Entrepreneurship and Collaboration.

Homburg, C., Droll, M., \& Totzek, D. (2008). Customer prioritization: Does it pay off, and how should it be implemented? Journal of Marketing, 72(5), 110-130. doi:10.1509/jmkg.72.5.110

Huin, S. F., Luong, L. H. S., \& Abhary, K. (2002). Internal supply chain planning determinants in small and medium-sized manufacturers. International Journal of Physical Distribution \& Logistics Management, 32(9), 771-782. doi:10.1108/09600030210452440

Ivens, B. S., \& Pardo, C. (2007). Are key account relationships different? Empirical results on supplier strategies and customer reactions. Industrial Marketing Management, 36(4), 470-482.

doi:http://dx.doi.org/10.1016/j.indmarman.2005.12.007

Ivens, B. S., \& Pardo, C. (2016). Managerial implications of research on inter-organizational interfaces: The case of key account management. IMP Journal, 10(1), 25-49. doi:doi:10.1108/IMP06-2015-0030

Jisr, R. E., \& Maamari, B. E. (2017). Effectuation: Exploring a third dimension to tacit knowledge. Knowledge and Process Management, 24(1), 72-78. doi:10.1002/kpm.1536

Johnston, M. W., \& Marshall, G. W. (2016). Sales force management: Leadership, innovation, technology: Routledge.

Kavak, B., Tunçel, N., \& Özyörük, H. E. (2015a). Do Small and Medium Sized Enterprises Have Their Unique Buying Behavior Variables?--A Qualitative Approach. International Journal of Trade, Economics and Finance, 6(6), 283-289.

Kavak, B., Tunçel, N., \& Özyörük, H. E. (2015b). Do small and medium sized enterprises have their unique buying behavior variables?- A qualitative approach. International Journal of Trade, Economics and Finance, 6(6), 283.

Kraljic, P. (1983). Purchasing must become supply management. Harvard Business Review, 61(5), 109-117.

La Rocca, A., Perna, A., Snehota, I., \& Ciabuschi, F. (2019). The role of supplier relationships in the development of new business ventures. Industrial Marketing Management, 80, 149-159. doi:https://doi.org/10.1016/j.indmarman.2017.12.008 
Lenny Koh, S. C., Demirbag, M., Bayraktar, E., Tatoglu, E., \& Zaim, S. (2007). The impact of supply chain management practices on performance of SMEs. Industrial Management \& Data Systems, 107(1), 103-124. doi:10.1108/02635570710719089

McGowan, P. (2018). The impact of effectuation on small firm buying decisions. IMP Journal, 12(3), 444-459.

McGowan, P. (2020). Sales failure: a review and future research directions. International Journal of Logistics Research and Applications, 1-28. doi:10.1080/13675567.2020.1726306

McKelvie, A., Chandler, G. N., DeTienne, D. R., \& Johansson, A. (2019). The measurement of effectuation: highlighting research tensions and opportunities for the future. Small Business Economics. doi:10.1007/s11187-019-00149-6

Morrissey, W. J., \& Pittaway, L. (2004). A study of procurement behaviour in small firms. Journal of Small Business and Enterprise Development, 11(2), 254-262. doi:doi:10.1108/14626000410537191

Morrissey, W. J., \& Pittaway, L. (2006). Buyer-supplier relationships in small firms: the use of social factors to manage relationships. International Small Business Journal, 24(3), 272-298.

doi:10.1177/0266242606063433

Nyadzayo, M. W., Casidy, R., \& Thaichon, P. (2020). B2B purchase engagement: Examining the key drivers and outcomes in professional services. Industrial Marketing Management, 85, 197-208. doi:https://doi.org/10.1016/i.indmarman.2019.11.007

Oumlil, A. B., \& Balloun, J. L. (2017). Cultural variations and ethical business decision making: a study of individualistic and collective cultures. Journal of Business \& Industrial Marketing, 32(7), 889-900. doi:10.1108/jbim-08-2016-0194

Panagopoulos, N. G., \& Avlonitis, G. J. (2010). Performance implications of sales strategy: The moderating effects of leadership and environment. International Journal of Research in Marketing, 27(1), 46-57. doi:http://dx.doi.org/10.1016/i.ijresmar.2009.11.001

Pfeffer, L., \& Khan, M. S. (2018). Causation and effectuation: An exploratory study of new zealand entrepreneurs. Journal of Technology Management \& Innovation, 13(1), 27-36.

Quayle, M. (2002). Purchasing in small firms. European Journal of Purchasing \& Supply Management, 8(3), 151-159. doi:http://dx.doi.org/10.1016/S0969-7012(02)00005-9

Sarasvathy, S. D. (2001a). Causation and effectuation: Toward a theoretical shift from economic inevitability to entrepreneurial contingency, 243.

Sarasvathy, S. D. (2001b, 2001/08//). Effectual reasoning in entrepreneurial decision making: Existance and bounds.

Sarasvathy, S. D. (2009). Effectuation: Elements of entrepreneurial expertise. Cheltneham UK: Edward Elgar Publishing.

Saunders, M., Lewis, P., \& Thornhill, A. (2012). Research methods for business students (6th ed.). Harlow, England ; New York: Pearson, 2012.

Seidman, I. (2013). Interviewing as qualitative research: A guide for researchers in education and the social sciences. New York, NY, US: Teachers college press. 
Seung-Kuk, P., Bagchi, P. K., Skjøtt-Larsen, T., \& Adams, J. H. (2009). Purchasing development in small and medium-sized enterprises (SMEs). Supply Chain Forum: International Journal, 10(1), 92-107.

Sharma, A. (2007). The metrics of relationships. Journal of Relationship Marketing, 6(2), 33-50. doi:10.1300/J366v06n02_04

Snehota, I., \& Hakansson, H. (1995). Developing relationships in business networks: Routledge London.

Terho, H., Eggert, A., Haas, A., \& Ulaga, W. (2015). How sales strategy translates into performance: The role of salesperson customer orientation and value-based selling. Industrial Marketing Management, 45, 12-21. doi:https://doi.org/10.1016/i.indmarman.2015.02.017

Thakkar, J., Kanda, A., \& Deshmukh, S. G. (2008). A conceptual role interaction model for supply chain management in SMEs. Journal of Small Business and Enterprise Development, 15(1), 74-95. doi:10.1108/14626000810850856

Turnbull, P., Ford, D., \& Cunningham, M. (1996). Interaction, relationships and networks in business markets: an evolving perspective. Journal of Business \& Industrial Marketing, 11(3/4), 44-62. doi:doi:10.1108/08858629610125469

Weitz, B. A., Castleberry, S. B., \& Tanner, J. F. (2011). Selling: building partnerships. New York, NY: McGraw-Hill/Irwin.

Welter, C., \& Kim, S. (2018). Effectuation under risk and uncertainty: A simulation model. Journal of business venturing, 33(1), 100-116. doi:https://doi.org/10.1016/j.jbusvent.2017.11.005

Welter, C., Mauer, R., \& Wuebker, R. J. (2016). Bridging behavioral models and theoretical concepts: Effectuation and bricolage in the opportunity creation framework. Strategic Entrepreneurship Journal, 10(1), 5-20. doi:10.1002/sej.1215

What is an SME. (2005). Retrieved from https://ec.europa.eu/growth/smes/business-friendlyenvironment/sme-definition en

Wynarczyk, P., \& Watson, R. (2005). Firm gowth and supply chain partnerships: An epirical analysis of UK SME subcontractors. Small Business Economics, 24(1), 39-51. doi:10.1007/s11187-005-3095-0

Yang, S. (2015). Understanding B2B customer loyalty in the mobile telecommunication industry: a look at dedication and constraint. Journal of Business \& Industrial Marketing, 30(2), 117-128. doi:10.1108/JBIM-05-2013-0105 